\title{
Nutritional regulation of IGF-II, but not IGF-I, is age dependent in sheep
}

\author{
J M Oldham, J A K Martyn, K M Hua, N A MacDonald, \\ S C Hodgkinson and J J Bass
}

Growth Physiology, Dairy and Beef Division, AgResearch Ruakura, Private Bag 3123, Hamilton, New Zealand

(Requests for offprints should be addressed to J M Oldham)

\begin{abstract}
In post-natal animals, plasma concentrations of IGF-I are tightly regulated by nutritional status. The current study reports that plasma levels of IGF-II in sheep are also regulated by nutrition, but whether plasma IGF-II is increased, decreased or remains the same, depends on the age of the animal. Ewe lambs, ranging in age from 2 days to 2 years, were fed or fasted for lengths of time between 24 and $72 \mathrm{~h}$. Blood samples were taken at intervals of $24 \mathrm{~h}$ throughout the treatment period and immediately before slaughter.

Plasma concentrations of IGF-I increased with advancing age in fed animals $(P<0 \cdot 001)$ and were reduced by fasting in all age groups $(P<0 \cdot 001)$. Plasma concentrations of IGF-II also increased as animals matured $(P<0 \cdot 001)$, but did not show an overall effect of the fasting treatment. An interaction between age and nutrition $(P<0 \cdot 001)$ resulted from a decrease in plasma IGF-II in response to fasting in neonatal animals $(P<0 \cdot 01)$ and, conversely, increased levels of plasma IGF-II in fasted mature animals $(P<0 \cdot 01$
\end{abstract}

or $P<0 \cdot 001)$. Fasted sheep of peripubertal age showed no change in plasma levels of IGF-II.

The nutritional sensitivity of serum IGF-binding proteins (BPs) also changed with age. The $29 \mathrm{kDa} \mathrm{BP}$, which we presume to be BP1, was elevated by fasting in young animals and reduced slightly in older animals. BP2 was increased to a similar magnitude by fasting at all ages. BP3 was depressed by fasting in young animals and showed little change in adults. In contrast, a $24 \mathrm{kDa}$ $\mathrm{BP}$, which is probably $\mathrm{BP} 4$, showed little change in young animals and was reduced substantially in older sheep.

In conclusion, the response of plasma IGF-II to fasting suggests that this peptide has functions in mediating nutritional stress which depend on the age of the animal, and also that the role of IGF-II may differ from that of IGF-I in adults.

Journal of Endocrinology (1999) 163, 395-402

\section{Introduction}

A major role of insulin-like growth factors (IGFs) is considered to be the regulation of tissue growth and differentiation. IGF-II is considered to be predominantly a foetal growth factor while IGF-I is of primary importance during post-natal growth. In many species it is now recognised that both IGFs are present in plasma and tissues of post-natal animals, and IGF-II is often at higher concentrations in plasma than IGF-I (Sohlstrom et al. 1998).

While it is well documented that the nutritional status of an animal markedly affects plasma levels of IGF-I (Bass et al. 1991, Monaco \& Donovan 1997), the response of IGF-II to poor nutrition has not been studied as extensively. In young rats, IGF-II in serum is decreased by nutritional restriction but is less sensitive in the short term than IGF-I (Donovan et al. 1991). Malnourished children have reduced serum concentrations of IGF-II (Soliman et al. 1986), although studies done in adults report no change in IGF-II levels following 5 days of fasting (Davenport et al. 1988). In ruminants, a number of reports suggest that fasting alters plasma levels of IGF-II. McGuire et al. (1995a) reported a reduction following 2 days of food deprivation in dairy cattle while Bass et al. (1984) also observed lower plasma IGF-II in 10 month sheep that were fasted for 5 days. A further study has also provided evidence that nutritional regulation of plasma IGF-II is age dependent in sheep, as fasting increased plasma IGF-II in mature ewes but not 4 month lambs (Hua et al. 1995).

These reports suggest that both IGF-I and IGF-II are regulated by nutrition, but they may be differentially controlled. We have systematically studied the effects of post-natal age and food deprivation on plasma levels of IGF-I, IGF-II and IGF-binding proteins (BPs) to investigate whether nutrition is a controlling factor of plasma IGFs at all ages in sheep, and whether the manner of regulation differs for each IGF. 
Table 1 Random allocation of sheep

\begin{tabular}{|c|c|c|c|c|c|c|}
\hline & \multicolumn{6}{|c|}{ Age and developmental stage of sheep } \\
\hline & \multicolumn{2}{|c|}{ Neonatal } & \multicolumn{2}{|c|}{ Peripubertal } & \multicolumn{2}{|l|}{ Adult } \\
\hline & 2 days & 14 days & 4 months & 6 months & 12 months & 24 months \\
\hline \multicolumn{7}{|l|}{ Treatment } \\
\hline Fed $(n)$ & 4 & 5 & 4 & 5 & 5 & 5 \\
\hline Fasted $(n)$ & 4 & 6 & 4 & 4 & 5 & 5 \\
\hline Fasting period $(h)$ & 24 & 24 & 48 & 72 & 72 & 72 \\
\hline
\end{tabular}

\section{Materials and Methods}

\section{Animals}

Female sheep ranging in age from 2 days to 2 years were obtained from the farm at Ruakura Research Centre and randomly allocated to experimental treatments as in Table 1. The ages for study were selected to encompass significant phases of post-natal development from birth to maturity, i.e. the initial growth response after birth, rapid growth around puberty and the slowing of growth at maturity. Details of care and feeding are published elsewhere (Oldham et al. 1996). Blood samples were taken from all animals at intervals of $24 \mathrm{~h}$ throughout the fasting period until slaughter. Blood (5 or $10 \mathrm{ml}$ ) was collected by jugular venepuncture into tubes containing EDTA for assay of IGFs, IGFBPs and glucose, or sodium oxalate for assay of non-esterified fatty acids (NEFA). The samples were chilled on ice, centrifuged $\left(2000 \mathrm{~g}, 4{ }^{\circ} \mathrm{C}\right)$ and the plasma stored at $-20{ }^{\circ} \mathrm{C}$ until assay. This experiment received approval from the Animal Ethics Committee at Ruakura Research Centre.

\section{IGF RIA}

Ovine IGF-I and IGF-II were radiolabelled using Iodogen as previously reported (Hodgkinson et al. 1989). The ${ }^{125}$ I-IGF peptides were purified using reversed-phase Sep-Pak (Waters Associates, Milford, MA, USA) and stored at $-20{ }^{\circ} \mathrm{C}$ until use.

IGF-I was dissociated from IGFBPs in plasma using acid/ethanol cryoprecipitation (Hodgkinson et al. 1991), which routinely has a recovery efficiency of $\sim 91 \%$ in adult sheep plasma (Hodgkinson 1991). IGF-II was extracted from plasma using C18 Sep-Pak (Waters Associates) (Jackson et al. 1991), showing a recovery of $82 \%$.

RIA for IGF-I and IGF-II was performed as reported by Hua et al. (1995). The IGF-I antibody was generated against a recombinant human amino-terminal methionyl IGF-I (IMC/Pitman Moore, Terre Haute, IN, USA) and the IGF-II antibody was a mouse monoclonal antibody against rat IGF-II (Amano Pharmaceutical Company Limited, Nagoya, Japan). Both assays cross-react $<1 \%$ with the heterologous IGF and $<0 \cdot 1 \%$ with insulin. Within and between assay variations were $<4$ and $<10 \%$ respectively for IGF-I and $<6$ and $<11 \%$ respectively for IGF-II.

\section{Assay of plasma metabolites}

Glucose in plasma was measured in duplicate using the Beckman Glucose Analyser 2 (Beckman, Palo Alto, CA, USA). Glucose standard (150 mmol/l) was measured after every 12 unknown samples and had a coefficient of variation of $1.8 \%$. An enzymatic colorimetric method of micro-assay was used for the measurement of NEFA (Demacker et al. 1982). Samples were assayed in duplicate, with a coefficient of variation of $1 \cdot 52 \%$.

\section{Ligand blotting for IGFBPs}

Aliquots of plasma were prepared for SDS-PAGE using a modified method of Laemmli (1970). Pooled plasma $(n=3$ per group) samples from blood collected at slaughter, and controls of normal sheep plasma and foetal lamb plasma, were diluted in sample buffer and dissociated by boiling, then electrophoresed on an acrylamide gel and transferred onto nitrocellulose membrane. The method for ligand blotting was modified from Hossenlopp et al. (1986). Membranes were washed and incubated with ${ }^{125}$ I-IGF-II (800 000 c.p.m.) for $24 \mathrm{~h}$ at room temperature. Subsequently, they were washed, dried and exposed against XAR-5 film (Eastman Kodak, Rochester, NY, USA) for 5 days with intensifying screens at $-70{ }^{\circ} \mathrm{C}$. Optical density values from the radiographic bands in each sample were determined by densitometry (Molecular Dynamics, Sunnyvale, CA, USA).

\section{Statistics}

Data from plasma samples at slaughter were adjusted before analysis by using pre-treatment concentrations as a covariate. Other data were log-transformed when necessary. Main effects analysis by ANOVA was used and data are presented as age and treatment means \pm S.E.D. or S.E.M. 

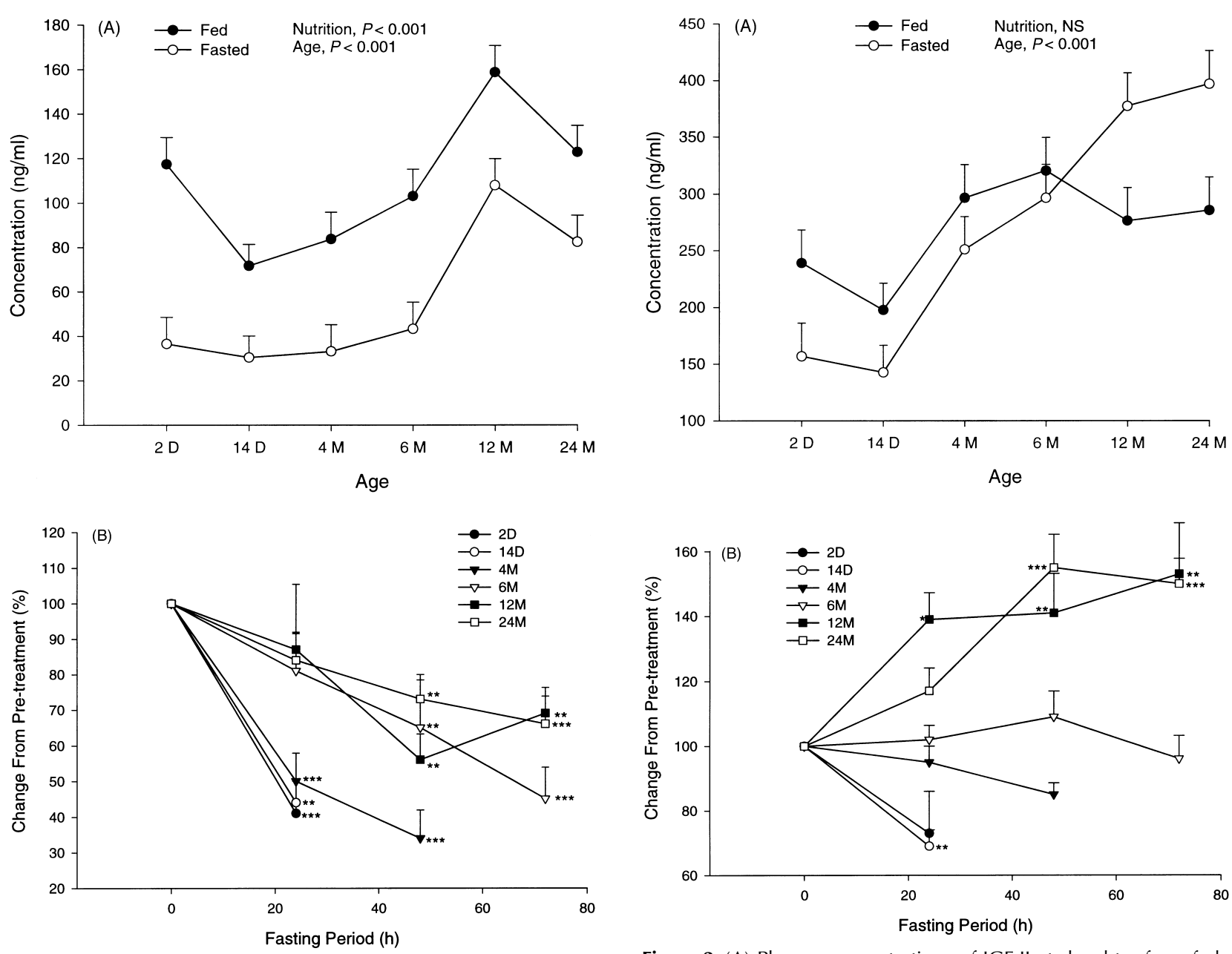

Figure 1 (A) Plasma concentrations of IGF-I at slaughter from fed and fasted sheep of different ages. (B) Plasma concentrations of IGF-I in fasted sheep of different ages at $24 \mathrm{~h}$ intervals during the treatment period. Time $0=$ pre-treatment $($ mean \pm pooled S.E.M., $\left.{ }^{* *} P<0 \cdot 01,{ }^{* * *} P<0 \cdot 001\right)$. $\mathrm{D}=$ days, $\mathrm{M}=$ months.

\section{Results}

\section{Plasma IGFs}

At slaughter, plasma concentrations of IGF-I (Fig. 1A) increased with age $(P<0 \cdot 001)$ and were reduced by fasting $(P<0 \cdot 001)$. Changes within individual groups showed progressively reduced concentrations of IGF-I at all ages in fasted lambs (Fig. 1B, $P<0 \cdot 01$ or $P<0 \cdot 001$ ). In fed lambs, the levels of IGF-I were relatively high in the neonatal period, before dropping and subsequently rising steadily to peak at 12 months. Developmental changes followed a similar pattern in fasted animals, with values $40-80 \mathrm{ng} / \mathrm{ml}$ lower than fed counterparts at the same age.

Plasma IGF-II increased with age $(P<0 \cdot 001)$ and there was a significant interaction between age and nutrition $(P<0 \cdot 001)$, but no main effect of the fasting treatment

Figure 2 (A) Plasma concentrations of IGF-II at slaughter from fed and fasted sheep of different ages. (B) Plasma concentrations of IGF-II in fasted sheep of different ages at $24 \mathrm{~h}$ intervals during the treatment period. Time $0=$ pre-treatment (mean \pm pooled S.E.M., $\left.{ }^{*} P<0 \cdot 05,{ }^{* *} P<0 \cdot 01,{ }^{* *} P<0 \cdot 001\right) . D=$ days,$M=$ months.

(Fig. 2A). This was due to age-related differences in the directional change of IGF-II as a result of fasting. The fasting treatment (Fig. 2B) reduced concentrations of IGF-II in younger animals $(P<0 \cdot 05)$ and increased concentrations in older animals $(P<0 \cdot 01$ or $P<0 \cdot 001)$. Developmental changes in the fed animals followed a similar pattern to that for IGF-I, with the exception that levels peaked at 6 months instead of 12 months.

\section{Plasma IGFBPs}

IGFBPs in circulation, as assessed qualitatively by a ligand blot of pooled plasmas at each age (Fig. 3A and B), were of samples taken from fasted animals at the onset of fasting and then at slaughter. This was $24 \mathrm{~h}$ later for 2 day and 14 day lambs, $48 \mathrm{~h}$ later for 4 month lambs and $72 \mathrm{~h}$ later for 6,12 and 24 month sheep. The IGFBPs showed 
A)
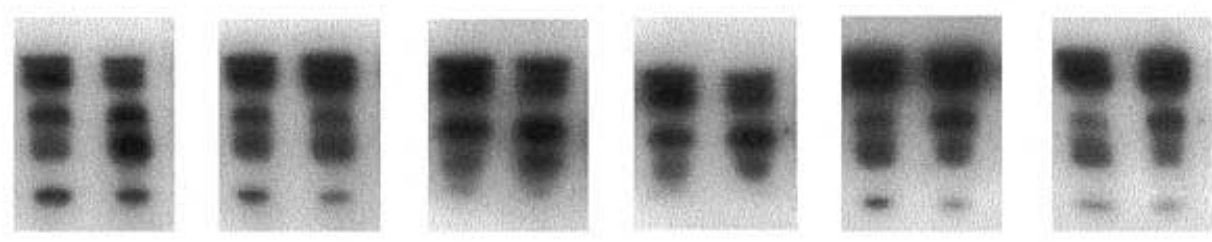

$\mathrm{kDa}$

$\begin{array}{cccccccccc}P \quad F & P & F & P & F & P & F & P & F & P \quad F \\ 2 D & 14 D & & 4 M & & 6 M & 12 M & 24 M\end{array}$

B)

$29 \mathrm{kDa}$

BP 2
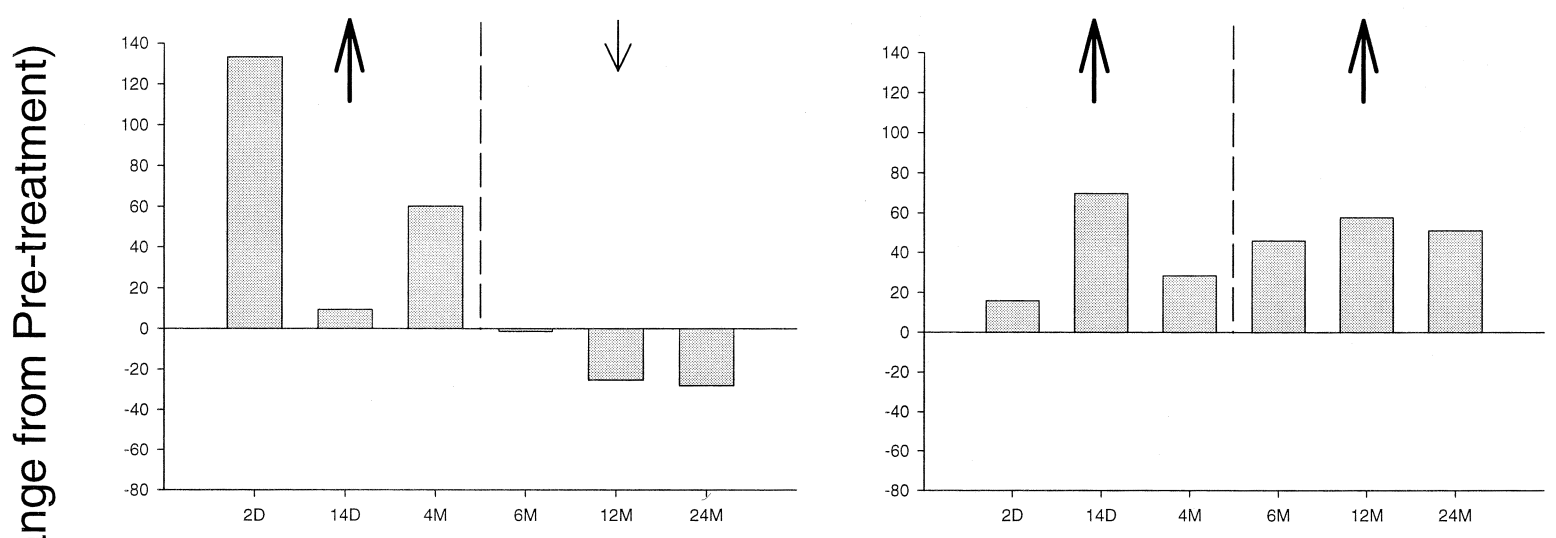

$\frac{5}{0}$

$\stackrel{0}{\varrho}$
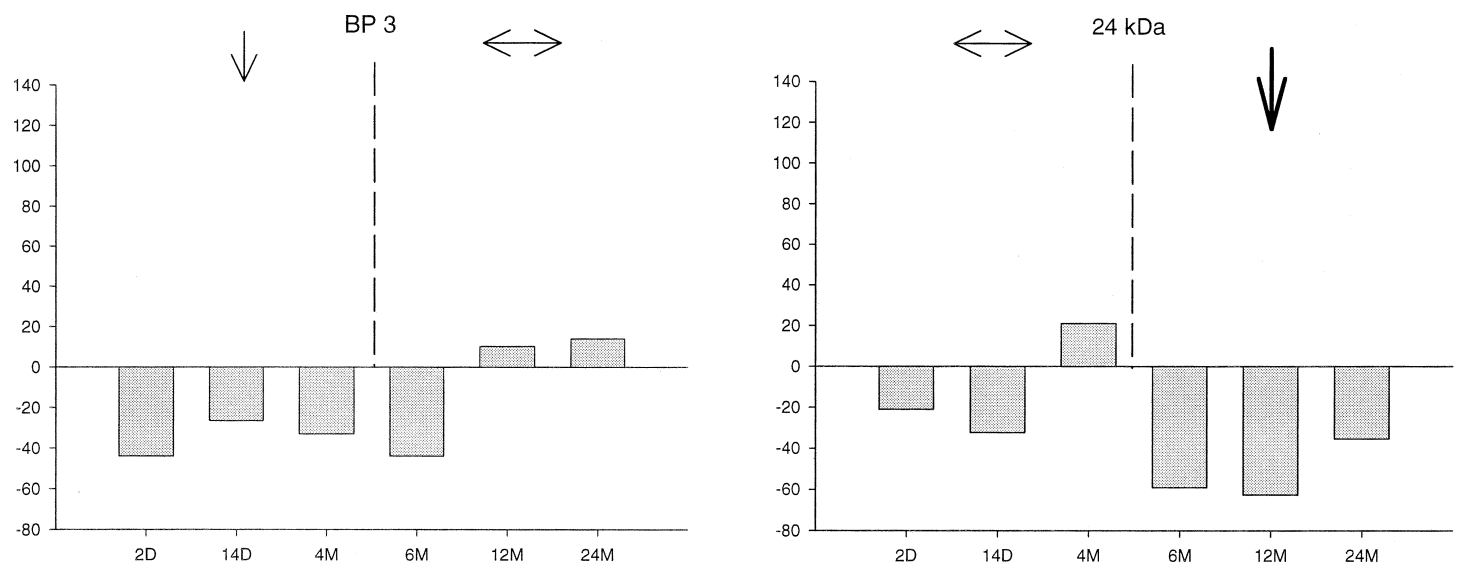

Age

Figure 3 (A) Ligand blot of serum IGFBPs in pooled pre-treatment (P) and final (F) samples from fasted sheep of different ages. (B) Fasting-induced changes in serum IGFBPs have been estimated by differences in optical density between pre-treatment samples and final samples at slaughter. Final samples were taken at $24 \mathrm{~h}$ for 2 day and 14 day lambs, $48 \mathrm{~h}$ for 4 month lambs and $72 \mathrm{~h}$ for 6,12 and 24 month sheep. Arrows indicate overall trends for younger and older sheep. $D=$ days, $M=$ months. 

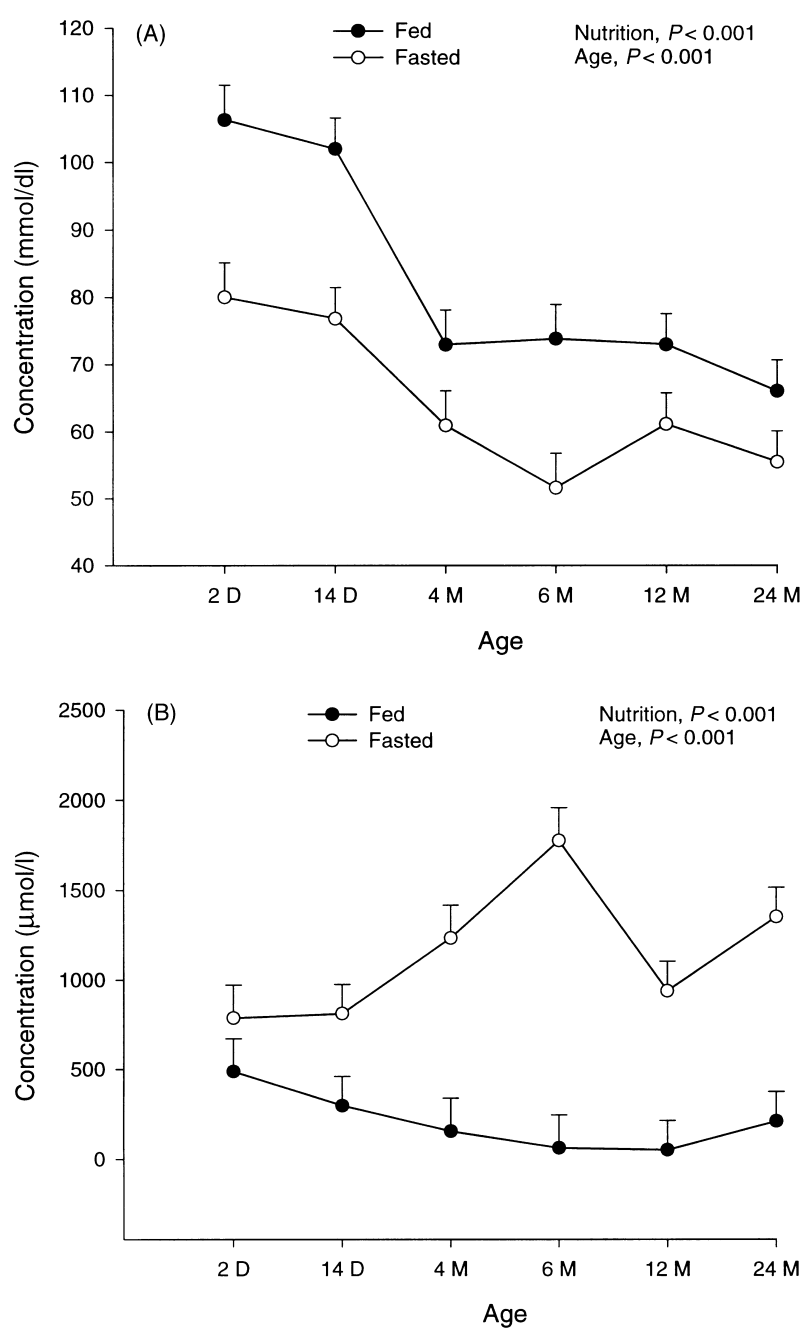

Figure 4 Plasma concentrations of (A) glucose and (B) NEFA at slaughter from fed and fasted sheep of different ages (mean \pm pooled S.E.M.). $\mathrm{D}=$ days, $\mathrm{M}=$ months.

different patterns of sensitivity to fasting, some of which were influenced by age of the lambs. The $29 \mathrm{kDa}$ protein, which is likely to be BP1, was increased by fasting in young animals and depressed by fasting in older animals. BP2 was elevated in response to fasting at each age. BP3 was depressed by fasting in younger animals and the $24 \mathrm{kDa}$ protein, possibly BP4 (Carr et al. 1994), was also depressed by fasting.

\section{Plasma metabolites}

Changes in glucose concentrations with age and nutrition were both significant (Fig. 4A, $P<0 \cdot 001$ ). Glucose levels in fed lambs declined steadily with increasing age but were always higher than in fasted counterparts. NEFA concentrations (Fig. 4B) declined with age in fed animals
$(P<0 \cdot 05)$ and concentrations were increased overall by fasting $(P<0 \cdot 001)$. There was an interaction between these variables $(P<0 \cdot 001)$ which is likely to have arisen from the greater response of NEFA to fasting in older animals.

\section{Discussion}

The data we present document responses of the endocrine IGF system to fasting. The primary finding is that plasma levels of IGF-II are nutritionally sensitive throughout much of post-natal life, but that the directional change as a result of fasting differs between young and older sheep. IGFBPs also show age-related responses to nutritional stress. If the expendable IGF function in the face of nutritional deficit is cellular growth, as suggested by McCusker (1998), then IGF levels in fasted animals may reflect an absolute requirement for cellular maintenance that is greatest in mature animals.

Generally, the pattern of increasing concentrations of IGF with advancing age is the same for IGF-I and IGF-II, so it may be speculated that both growth factors are regulated by growth hormone $(\mathrm{GH})$ and the appearance of the hepatic GH receptor (Gluckman et al. 1983). While there is no doubt that plasma IGF-I is positively regulated by GH (Bass et al. 1991), the relationship of GH with IGF-II has not been well defined. GH treatment reduces plasma IGF-II in sheep, regardless of age or nutritional status (Hua et al. 1995) so it is possible that a decline in plasma GH with advancing age (data not presented) is permissive in increasing post-natal levels of IGF-II in plasma.

The resistance of plasma IGFs to change in the face of nutritional stress is also developmentally regulated, tolerance in very young animals being less than in older animals. The more immediate reduction of plasma IGF-I in young fasted animals may be a response reflecting a greater dependence on glucose synthesis and metabolism than mobilisation of fatty acids. This is supported by metabolite data showing greater reductions in glucose and smaller increases in NEFA in fasted young lambs when compared with mature sheep. The response of NEFA to treatment with GH or IGF-I may also be age dependent. In sheep, Bass et al. (1992) reported a dose-dependent increase in NEFA as a result of daily treatment with GH, but neonatal calves do not alter NEFA in response to treatment with GH or IGF-I (Hammon \& Blum 1997).

Results from other studies suggest that IGF-I clearance from plasma in older sheep does not alter with fasting (Hodgkinson et al. 1987). Further, hepatic IGF-I mRNA is reduced in poorly fed lambs (Pell et al. 1993). These studies indicate that nutritionally driven changes in plasma IGF-I in older animals are probably the result of altered hepatic production of IGF-I. IGF clearance rates in sheep of different ages have not been investigated, but a comparison of two independent reports suggests that the 
metabolic clearance of IGF-I is greater in 6- than 9-month-old wethers (Hodgkinson et al. 1987, Davis et al. 1989). Also, the clearance rate is greater for IGF-II than IGF-I (Hodgkinson et al. 1989). Regardless of changes in IGF production and secretion, a change in clearance rate may also contribute significantly to the developmental increases in circulating concentrations of IGFs that are reported in the current study.

Ratios of IGFBPs are useful correlates of clearance rate. A comparison of $\mathrm{BP} 3: \mathrm{BP} 1+\mathrm{BP} 2$ at different ages in the fed animals (data not shown) shows an increase in the ratio with advancing age, which supports the concept of a relative shift from smaller to larger IGFBP complexes and a possible decrease in IGF clearance associated with this. Plasma levels of BP3 and acid-labile subunit increase in concert with IGF-I during post-natal development of rats (Frystyk et al. 1998), and together may provide the binding capacity to account for some of the increase in plasma IGF observed with advancing age.

Our data on changes in plasma IGF-II as a result of fasting demonstrate the complexity of this response, and provide a framework for the evidence that IGF-II is nutritionally regulated at some ages but not others. Serial IGF-II levels throughout each fasting period corroborates the comparison made between fed and fasted lambs at slaughter. Overall, the response of IGF-II to fasting cannot be considered less sensitive than that of IGF-I, as two of the four groups in which changes in IGF-II were apparent differed significantly from pre-treatment by $24 \mathrm{~h}$.

The directional change in plasma IGF-II in response to fasting occurs as plasma levels of IGF-II peak developmentally at 6 months. This age coincides with both puberty and a significant decline in growth rate (Fourie 1965) and we have previously speculated that it may also be associated with a transition for the IGF axis from growth promotion to metabolic homeostasis (Oldham et al. 1996, Martyn et al. 1997). In the adult animal, elevated levels of IGF-II as a consequence of fasting may be associated with a down-regulation of metabolic IGF actions in mature muscle. If secretion of IGF-II is increased in the adult as a result of fasting, this suggests that IGF-II may play a positive role in the adaptive response of the animal. Evidence for such a role has been reported previously, with IGF-II infusion blocking the anabolic effects of IGF-I on animals in a catabolic state (Koea et al. 1992a,b). Alternatively, elevated IGF-II together with reduced IGF-I may allow metabolic homeostasis to continue at the expense of cellular growth. Such actions may be controlled by insulin. Under conditions of hyperinsulinaemia and euglycaemia, IGF-I concentrations in adult cattle are elevated while IGF-II levels are depressed (McGuire et al. 1995b), so it may be a reduction of insulin by fasting which is directly regulating the changes in plasma IGFs.

Species and developmental differences exist in the response of IGF-II to nutritional stress. IGF-II is reduced with fasting in adult cattle (McGuire et al. 1995a) and humans (Merimee et al. 1982) and by malnutrition in children (Soliman et al. 1986, Pucilowska et al. 1993). In contrast, nutritional restriction but not fasting causes a reduction of plasma IGF-II in guinea-pigs (Sohlstrom et al. 1998). Pregnancy is a further state in which the response of IGF-II may differ from that which we report, as fasting of pregnant ewes reduces IGF-II in plasma while restricted nutrition does not (Bauer et al. 1995, Lee et al. 1997).

The preliminary data that we report for patterns of fasting-induced changes in serum IGFBPs, differed for each of the four main species of IGFBP. The $29 \mathrm{kDa}$ IGFBP, likely to be BP1, changed in a manner inversely mirroring the response to nutrition by IGF-II. This relationship has not been previously demonstrated, although the relationship of BP1 with insulin and glucagon (Nygren et al. 1997) and the role of BP1 in glucose regulation (Mortenson et al. 1997) are well documented. The nutritional change in $\mathrm{BP} 1$ from an increase in young animals to a small decrease in older animals may also be indicative of a change in emphasis from glucose to fatty acid metabolism when animals are nutritionally stressed. As in other studies (McGuire et al. 1995a, Monaco \& Donovan 1997), levels of BP2 were increased by nutritional stress and Murphy (1998) suggests that this assists in the maintenance of nutritional homeostasis, in contrast to glucose regulation by BP1, by retarding IGF clearance from plasma.

$\mathrm{BP} 3$, like BP1, showed a developmental change in response to fasting. Adult animals did not alter plasma levels of BP3, as is also the situation in fasted dairy cattle (McGuire et al. 1995a), despite marked differences in both IGF-I and IGF-II. The ratio of tertiary and binary IGF and IGFBP complexes is a regulatory control of IGF clearance from plasma (McCusker 1998). In nutritional deficit, the ratio of $\mathrm{BP} 3: \mathrm{BP} 1+\mathrm{BP} 2$ reduces, the consequence of this being the increased clearance of IGFs to peripheral tissues. Certainly, this appears to be the case in young animals but the relationship breaks down in older animals as neither BP3 nor BP1 levels alter markedly. The $23 \mathrm{kDa}$ IGFBP, which we presume to be BP4, was depressed at most ages by fasting. BP4 impedes IGF action in culture systems (McCusker 1998) and is reduced by poor nutrition (Holt et al. 1996, Takenaka et al. 1996). Reduction of BP4, in conjunction with changes in clearance and/or secretion of IGF, seems to be an appropriate response if basal metabolic functions of IGFs are to be maintained in the face of nutritional stress.

In conclusion, we believe that the differential response of plasma IGF-II to fasting in young and mature sheep is a consequence of a change in the post-natal role of IGF-II from promoting growth to controlling cell metabolism, possibly by regulation of IGF-I actions in target tissues.

\section{Acknowledgements}

The authors gratefully acknowledge the contributions of others to this work. Mr J Napier performed iodinations 
and Mr R Lasenby, Mr T Watson and Mr M Holmes cared for the animals. Dr L Moore provided ovine IGF-I and IGF-II, and advice on statistics was received from Dr N Cox. This research was supported through funding from the New Zealand Foundation for Research, Science and Technology.

\section{References}

Bass J, Davis S, Peterson A, Gluckman P, Butler J \& Gray M 1984 Effects of different diets and starvation on concentrations of somatomedins and other growth controlling hormones of wether lambs. Proceedings of the Endocrine Society of Australia 27 (Suppl) 15.

Bass JJ, Oldham JM, Hodgkinson SC, Fowke PJ, Sauerwein H, Molan P, Breier BH \& Gluckman PD 1991 Influence of nutrition and bovine growth hormone $(\mathrm{GH})$ on hepatic $\mathrm{GH}$ binding, insulin-like growth factor-I and growth of lambs. Journal of Endocrinology 128 181-186.

Bass JJ, Hodgkinson SC, Breier BH, Carter WD \& Gluckman PD 1992 Effects of bovine somatotrophin on insulin-like growth factor-I, insulin, growth and carcass composition of lambs. Livestock Production Science 31 321-334.

Bauer MK, Breier BH, Harding JE, Veldhuis JD \& Gluckman PD 1995 The fetal somatotropic axis during long term maternal undernutrition in sheep: evidence for nutritional regulation in utero. Endocrinology 136 1250-1257.

Carr JM, Grant PA, Francis GL, Owens JA, Wallace JC \& Walton PE 1994 Isolation and characterization of ovine IGFBP-4: protein purification and cDNA sequence. Journal of Molecular Endocrinology 13 219-236.

Davenport ML, Svoboda ME, Koerber KL, Van Wyk JJ, Clemmons DR \& Underwood LE 1988 Serum concentrations of insulin-like growth factor II are not changed by short-term fasting and refeeding. Journal of Clinical Endocrinology and Metabolism 67 1231-1236.

Davis SR, Hodgkinson SC, Moore LG \& Gluckman PD 1989 Improved estimates of clearance of ${ }^{131}$ I-labelled insulin-like growth factor-I carrier protein complexes from blood plasma of sheep. Journal of Endocrinology 123 469-475.

Demacker PN, Hijmans AG \& Jansen AP 1982 Enzymic and chemical-extraction determinations of free fatty acids in serum compared. Clinical Chemistry 28 1765-1768.

Donovan SM, Atilano LC, Hintz RL, Wilson DM \& Rosenfeld RG 1991 Differential regulation of the insulin-like growth factors (IGF-I and -II) and IGF binding proteins during malnutrition in the neonatal rat. Endocrinology 129 149-157.

Fourie PD 1965 Growth and development of sheep with special reference to New Zealand breeds. Unpublished DSc Thesis. University of Pretoria, Pretoria, South Africa.

Frystyk J, Gronbaek H, Scjaerbaek C, Flyvbjerg A, Orskov H \& Baxter RC 1998 Developmental changes in serum levels of free and total insulin-like growth factor I (IGF-I), IGF-binding protein-1 and -3 , and the acid-labile subunit in rats. Endocrinology 139 4286-4292.

Gluckman PD, Butler JH \& Elliott TB 1983 The ontogeny of somatotropic binding sites in ovine hepatic membranes. Endocrinology 112 1607-1612.

Hammon H \& Blum JW 1997 The somatotropic axis in neonatal calves can be modulated by nutrition, growth hormone and long-R ${ }^{3}$-IGF-I. American Journal of Physiology 273 E130-E138.

Hodgkinson SC 1991 Insulin-like growth factors and their binding proteins in post-natal ruminants. Unpublished $P h D$ Thesis. University of Auckland, Auckland, New Zealand.

Hodgkinson SC, Davis SR, Burleigh BD, Henderson HV \& Gluckman PD 1987 Metabolic clearance rate of insulin-like growth
factor-I in fed and starved sheep. Journal of Endocrinology 115 233-240.

Hodgkinson SC, Davis SR, Moore LG, Henderson HV \& Gluckman PD 1989 Metabolic clearance of insulin-like growth factor-II in sheep. Journal of Endocrinology 123 461-468.

Hodgkinson SC, Bass JJ \& Gluckman PD 1991 Plasma IGF-I binding proteins in sheep: effect of recombinant growth hormone treatment and nutritional status. Domestic Animal Endocrinology 8 343-351.

Holt RI, Baker AJ, Jones JS, Crossey PA, Stone NM, Preedy VR \& Miell JP 1996 Differential effects of malnutrition, bile duct ligation and galactosamine injection in young rats on serum levels and gene expression of IGF-binding proteins. Journal of Endocrinology 149 465-472.

Hossenlopp P, Seurin D, Segovia-Quinson B, Hardouin S \& Binoux M 1986 Analysis of serum insulin-like growth factor binding proteins using western blotting: use of the method for titration of the binding proteins and competitive binding sites. Analytical Biochemistry 154 138-143.

Hua KM, Hodgkinson SC \& Bass JJ 1995 Differential regulation of plasma levels of insulin-like growth factors-I and -II by nutrition, age and growth hormone treatment in sheep. Journal of Endocrinology 147 507-516.

Jackson S, Hodgkinson S, Estivariz FE \& Lowry PJ 1991 IGF1 and IGF2 in two models of adrenal growth. Journal of Steroid Biochemistry and Molecular Biology 40 399-404.

Koea JB, Breier BH, Shaw JH \& Gluckman PD 1992a A possible role for IGF-II: evidence in sheep for in vivo regulation of IGF-I mediated protein anabolism. Endocrinology 130 2423-2425.

Koea JB, Douglas RG, Breier BH, Shaw JHF \& Gluckman PD $1992 b$ Synergistic effect of insulin-like growth factor-I administration on the protein sparing effects of total parenteral nutrition in fasted lambs. Endocrinology 131 643-648.

Laemmli UK 1970 Cleavage of structural proteins during the assembly of the head of bacteriophage T4. Nature 227 680-685.

Lee WH, Gaylord TD, Bowsher RR, Hlaing M, Moorehead H \& Liechty EA 1997 Nutritional regulation of circulating insulin-like growth factors (IGFs) and their binding proteins in the ovine fetus. Endocrine Journal 44 163-173.

Martyn JAK, Oldham JM, Napier JR, Hodgkinson SC \& Bass JJ 1997 Regulation by nutrition and age of insulin-like growth factor binding sites in ovine kidney. Journal of Experimental Zoology 277 382-389.

McCusker RH 1998 Controlling insulin-like growth factor activity and the modulation of insulin-like growth factor binding protein and receptor binding. Journal of Dairy Science 81 1790-1800.

McGuire MA, Bauman DE, Dwyer DA \& Cohick WS 1995 a Nutritional modulation of the somatotropin/insulin-like growth factor system: response to feed deprivation in lactating cows. Journal of Nutrition 125 493-502.

McGuire MA, Dwyer DA, Harrell RJ \& Bauman DE 1995 b Insulin regulates circulating insulin-like growth factors and some of their binding proteins in lactating cows. American Journal of Physiology 269 E723-E730.

Merimee TJ, Zapf J \& Froesch ER 1982 Insulin-like growth factors in the fed and fasted states. Journal of Clinical Endocrinology and Metabolism 55 999-1002.

Monaco MH \& Donovan SM 1997 Moderate food restriction reduces serum IGF-I and alters circulating IGF-binding protein profiles in lactating rats. Journal of Endocrinology 152 303-316.

Mortenson DL, Won WB, Siu J, Reifsnyder D, Gironella M, Etcheverry T \& Clark RG 1997 Insulin-like growth factor binding protein-1 induces insulin release in the rat. Endocrinology 138 2073-2080.

Murphy LJ 1998 Insulin-like growth-factor binding proteins: functional diversity or redundancy? Journal of Molecular Endocrinology 21 97-107. 
Nygren J, Thorell A, Brismar K, Karpe F \& Ljungqvist O 1997 Short-term hypocaloric nutrition but not bed rest decrease insulin sensitivity and IGF-I bioavailability in healthy subjects: the importance of glucagon. Nutrition 13 945-951.

Oldham JM, Martyn JAK, Kirk SP, Napier JR \& Bass JJ 1996 Regulation of type 1 insulin-like growth factor (IGF) receptors and IGF-I mRNA by age and nutrition in ovine skeletal muscles. Journal of Endocrinology 148 337-346.

Pell JM, Saunders JC \& Gilmour RS 1993 Differential regulation of transcription initiation from insulin-like growth factor-I (IGF-I) leader exons and of tissue IGF-I expression in response to changed growth hormone and nutritional status in sheep. Endocrinology 132 1797-1807.

Pucilowska JB, Davenport ML, Kabir I, Clemmons DR, Thissen J-P, Butler T \& Underwood LE 1993 The effect of dietary protein supplementation on insulin-like growth factors (IGFs) and IGF-binding proteins in children with shigellosis. Journal of Clinical Endocrinology and Metabolism 77 1516-1521.
Sohlstrom A, Katsman A, Kind KL, Grant PA, Owens PC, Robinson JS \& Owens JA 1998 Effects of acute and chronic food restriction on the insulin-like growth factor axis in the guinea pig. Journal of Endocrinology 157 107-114.

Soliman AT, Hassan AI, Aref MK, Hintz RL, Rosenfeld RG \& Rogol AD 1986 Serum insulin-like growth factors I and II concentrations and growth hormone and insulin responses to arginine infusion in children with protein-energy malnutrition before and after nutritional rehabilitation. Pediatric Research 20 1122-1130.

Takenaka A, Mori M, Yamada S, Ohgane J, Takahashi S-I \& Noguchi T 1996 Nutritional regulation of gene expression of insulin-like growth factor-binding proteins and the acid-labile subunit in various tissues of rats. Journal of Endocrinology $\mathbf{1 5 0}$ $33-41$.

Received 19 February 1999

Accepted 20 July 1999 